\title{
Natural Resources and Conflict
}

\section{Dominic Rohner, University of Lausanne ${ }^{l}$}

November 13, 2017

Key Words: Resource Curse, Natural Resources, Conflict, Civil War.

JEL Codes: D74, F51, H56, Q30.

\section{Introduction}

Armed conflict is destructive in various ways. The first and obvious impact of war is that it kills and injures people: Between 1945 and 1999 an estimated 3.3 million people got killed in 25 interstate wars, and 16.2 million in 127 civil wars (Fearon and Laitin, 2003). Diseases and other indirect effects more than double this death toll (Ghobarah et al., 2003).

Also the economic consequences of war are very substantial: According to Collier (2007), civil wars reduce economic growth on average by 2.3 percent per year, and the average civil war lowers GDP by about 15 percent (when comparing the first year after conflict with the last year before conflict), while the direct and indirect costs of an average civil war can be estimated at around \$ 64 billion.

On top of this, substantial evidence shows that -unsurprisingly- conflict harms physical and mental health (see e.g. Barenbaum et al., 2004) and that it deteriorates schooling and long-run educational outcomes (see e.g. Shemyakina, 2011). Finally, there is a lively debate on the social impact of war, with some papers finding that conflict reduces inter-group trust (Rohner et al., 2013), and makes war victims more likely to engage in crime or conflict later in life (Couttenier et al., 2016), while other work finds conflict to boost local collective action (see the survey of Bauer et al., 2016). It has also been documented that a country exposed to conflict today is more likely to experience it also in the future, which may magnify the costs of conflict breaking out. ${ }^{2}$

\footnotetext{
${ }^{1}$ Acknowledgements: Helpful comments by the section editor, Roger Fouquet, have substantially improved this paper. Financial support from the ERC Starting Grant 677595 "Policies for Peace" is gratefully acknowledged.

${ }^{2}$ See e.g. Rohner et al. (2013b). In particular, it has been found that two thirds of conflict onsets have taken place in countries with multiple conflicts recorded (Collier and Hoeffler, 2004), and three quarters of civil wars are driven by enduring inter-ethnic rivalries (DeRouen and Bercovitch, 2008).
} 
Given this multi-dimensional and by any means substantial effect of war on society, it is crucial to understand the underlying drivers of conflict. ${ }^{3}$ One factor that has been singled out as a main determinant of conflict behavior has been the abundance of natural resources, which is the topic of the current contribution. ${ }^{4}$ In particular, this article aims to provide a well-structured synthesis of the theoretical and empirical literature linking natural resources to conflict. ${ }^{5}$

From a conceptual perspective, a rich theoretical literature has identified several major channels through which natural resources magnify the risk of civil conflict. First, the presence of natural resources increases the "prize" that can be seized through the capture of the territory or the state -- which has been referred to as "greed" or "rent-seeking". Second, natural resources make rebellion more feasible and longer lasting, i.e. looting and extortion relax financing constraints and make it easier to set up and sustain a rebel movement. Third, weak state capacity and extractive institutions may be a further consequence of resource wealth: Rentier states can rely on resource rents and do not build enough state capacity and good institutions, which makes them less effective in counterinsurgency and eventually more instable. Fourth, given that natural resource production is capital intensive, a resource price increase will boost capital-intensive production, and shrink labor-intensive sectors, which frees up cheap labor for rebellion. Fifth, when the territorial distribution of natural resources is unequal, resource-rich minority regions may have incentives to fight for secession. Sixth, the inter-temporal incentives for committing mass killings are fostered by large natural resource holdings. Finally, natural resources can in addition exacerbate grievances, due to frustrations from environmental degradation or banned access to lucrative mining jobs.

Finally, it is important to also point out that in principle there could well also exist mechanisms through which natural resource abundance lowers the conflict risk, as discussed in more detail below. The empirical literature on the conflict-resources nexus is also manifold. After the pioneering contributions establishing the stylized correlation, the literature has focused on i) finding more accurate measures of resource abundance, and ii) putting in place a more convincing identification strategy. The most recent trend has been to use very fine-grained geo-referenced micro-data, allowing to connect the empirics to the theory and to gain further insights on the mechanism and channels at work.

The current contribution is structured as follows: In Section 2 we shall discuss - one by one- the main theoretical channels linking natural resources to conflict highlighted in the existing literature, while Section 3 is dedicated to an account of recent empirical advances. Section 4 concludes.

\footnotetext{
${ }^{3}$ The focus of the current contribution lies of civil wars, which make up for the lion's share of conflicts in recent times, but I shall also at times refer to interstate wars.

${ }^{4}$ Existing reviews of the literature on the impact of natural resources include van der Ploeg (2011).

${ }^{5}$ In this paper I focus on natural resources that are either non-renewable (such as oil or minerals) or that are illegal (such as narcotics). The study of agricultural commodities is beyond the scope of this contribution.
} 


\section{The Theoretical Mechanisms}

\subsection{The Prize / Rent-seeking Effect}

One of the main channels of the resource-conflict nexus focused upon by scholars is that the presence of natural resources increases the "prize" (or "cake") that is up for grab. Put bluntly, if nothing can be stolen, there is not much point in fighting, while higher rewards attract higher fighting effort. This effect can easily be spotted in a typical "rent-seeking" conflict model using contest success functions. Consider the simplest form of such a static, simultaneous move game with two players, $\mathrm{i}, \mathrm{j}$, and

$$
\pi_{i}=R \frac{f_{i}}{f_{i}+f_{j}}-c f_{i}
$$

where $\pi_{i}=$ payoff function of player $\mathrm{i}$ (the one for $\mathrm{j}$ is analogous), $R=$ natural resource rents, $f_{i}=$ fighting effort of $\mathrm{i}, f_{j}=$ fighting effort of $\mathrm{j}$, $\mathrm{c}=$ cost parameter of fighting effort.

In such a standard simplified workhorse model the Nash Equilibrium is given by $f_{i}^{*}=f_{j}^{*}=R /(4 c)$, implying that equilibrium fighting efforts are an increasing function of natural resource rents $R$.

Such a logic of natural resource wealth boosting rent-seeking incentives has for example been applied in the models of Reuveny and Maxwell (2001), Grossman and Mendoza (2003), Hodler (2006), van der Ploeg and Rohner (2012), Caselli and Coleman (2013) and van der Ploeg (2017).

\subsection{Relaxing financing constraints of rebellion}

Take the workhorse model described in section 2.1 above, but assume that there is some fixed cost lump sum weaponry investment required to have positive fighting strength, i.e. take the formula of above but have now $f_{i}$ denote actual fighting strength and introduce fighting effort $e_{i}$, where $f_{i}=e_{i}$ if $e_{i} \geq \bar{e}$, while $f_{i}=0$ if $e_{i}<\bar{e}$. If wanna-be rebel leaders in such a setting are cash constrained, then the access to valuable natural resources can relax their cash constraints and make them able to reach the minimum fighting effort threshold to build an army.

In the literature it has indeed been found that natural resources make rebellion more feasible and enable rebels to sustain their armed opposition over a longer time period (Fearon, 2004; Collier, Hoeffler and Rohner, 2009; Berman et al., 2017). In particular, it has also been found that capturing a mineral extraction area results in a given rebel group expanding their zone of fighting in the next period (Berman et al., 2017).

\subsection{Weak state capacity}

A state that does not have to raise taxes to assure its functioning but can instead rely mostly on natural resource rents has lower incentives to build up fiscal capacity in particular and state capacity in general. While the effects of having such a weak state apparatus are not immediately noticeable in the middle of the natural resource boom, they typically have a negative impact on the state's capability to persist during crises, leading to political instability. This mechanism has among others been studied by Fearon (2005), Besley and Persson (2011) and Bell and Wolford (2015). 
Natural resource wealth has also been observed to fuel corruption and populism, which is an additional force driving down the efficiency of the state administration (see e.g. Baland and Francois, 2000; Ross 2012; Caselli and Michaels 2013; and Matsen et al., 2017).

\subsection{Capital intensiveness of natural resource extraction}

Dal Bo and Dal Bo (2011) include an appropriation sector in a general equilibrium model with as factors of production capital and labor. Assuming that appropriation is relatively labor intensive, they show that a price boom in the capital intensive natural resource sector soaks up capital from the other sectors, which lead to a drop in wages and hence reduced opportunity costs of appropriation, boosting conflict. This is in line with the findings of Dube and Vargas (2013) for oil and coffee in Columbia.

\subsection{Resource inequality and conflict}

The dangerous effects of natural resources abundance on rent-seeking, financing of fighting and state capacity can be exacerbated in the presence of existing ethnic divisions and inequalities. If a major resource producer is ethnically relatively homogenous (think of Norway) or resources are distributed rather evenly in the territory (think of the Gulf states), it is easier to contain the destructive forces of a potential resource curse than if resources are concentrated in a given region of an ethnically divided country. Things get worse still if the oil rich region coincides with the homelands of an ethnic or religious minority group (Morelli and Rohner, 2015). In this scenario the resource-rich minority group has powerful incentives to seek secession, as illustrated by the separatist movements in Aceh (Indonesia), Timor-Leste (ex-Indonesia), the Niger-Delta (Nigeria), South Sudan, Yemen, or Kurdistan (Iraq), among many others.

A similar logic of resource asymmetry fueling conflict applies as well to inter-state interactions. Caselli et al. (2015) make the following point: If two countries in a dyad have similar resource holdings, what they can gain in war is similar to what they can lose. However, if one country has larger resource deposits than the other it constitutes an attractive prey for the resource-poor opponent who itself has less to lose from war. The incentives for attacking are magnified further when the resources are close to the bilateral border, as relatively modest territorial gains can allow the resource-poor attacker to grab the loot.

\subsection{Mass Killings of Civilians}

Esteban et al. (2015) point out that the presence of large natural resource deposits may increase a cynical government's incentives to turn its arms against its own people. In their dynamic model, the government is able to eliminate (by killings or displacements) a part of the opposition population group. What it gains is a higher chance of being able to grab a larger share of the country's rents in the longrun, while of course a smaller population means less rents to be grabbed. And this "shrinking pie" effect is shown to be larger the bigger the importance of productive labor in the economic output. In particular, it is shown that in a country with very few natural resources it is usually not worthwhile even for the most cynical government-to reduce its opposition size, as the gain in the share of the "pie" is dominated by the loss due to the "pie" becoming smaller. In contrast, in a petro-state where much of economic output can be produced independently of the size of the local population, the cruel calculations of cynical leaders may tilt towards mass killings of opposition minorities. 


\subsection{Grievances by local population}

There is also a literature stressing that local social tensions can be fueled by the fact that often the local population loses out as far as resource production is concerned. While it suffers from environmental degradation it often only reaps a slim share of the economic benefits in terms of e.g. job opportunities. Contributions focusing on this include Le Billon (2001), Ross (2004), and Humphreys (2005). The "rough" environments created in mining towns can also result in a persistent, general rise in crime and homicides, as found by Couttenier et al. (2017). In line with this channel, it has been found that the conflict risk is magnified in mining areas where the exploiting firm has bad corporate governance records (Berman et al., 2017).

\subsection{Potential beneficial effects of resource wealth reducing the scope of conflict}

In terms of theoretical channels, one could well think that the presence of natural resources could reduce the scope of war by for example making redistribution easier to finance, or by providing employment opportunities to the local population, thereby increasing the opportunity cost of fighting. The trade-off is then that on the one hand the presence of valuable resources increases the gains of rebellion, while on the other hand the better job market prospects increase the opportunity cost of fighting. One factor limiting the relevance of this opportunity cost channel is the fact that resource extraction is relatively capital-intensive (as discussed above under section 2.4) and makes use of very specialized staff, which implies that often local labor is of limited importance and the boost provided for the local economy is relatively modest.

Empirically speaking, while there are indeed instances where oil wealth has arguably helped to "buy off" popular discontent (like recently in certain Gulf states during the Arab Spring), there does not exist compelling, large-scale evidence of this conflict-reducing effect of valuable resources. Angrist and Kugler (2008), for example, find hardly any substantial, positive effects of Coca production in Columbia on the local economy.

Going beyond the direct effects of local employment opportunities and short-run chances for buying-off popular discontent, one can also make the more general point that-at least potentially-natural resource abundance could foster long-run economic development which is a major factor contributing to political stability (see e.g. Collier et al., 2009). Whether natural resources can indeed contribute indirectly to peace by fostering long-run development very much depends on institutions, which is central to the positive or negative effects resource abundance has on economic performance (Mehlum et al., 2006; Clay, 2011).

Positive effects of natural resources on economic performance have for example be detected for countries with strong institutions such as the United States or Botswana. For instance, Wright and Czelusta (2007) have shown how, in the United States, resource and, in particular, coal abundance has led to the establishment of a number of major educational institutions and knowledge for other sectors of the economy. In the same vain, Hillbom (2015) shows that in Botswana natural resource wealth has favored a good economic record (although at the cost of specialization dependence). The potential 
growth effects of natural resources -if well managed-could indeed in principle reduce the scope for conflict.

\section{Recent empirical findings}

Below we shall discuss recent empirical results in the literature, discussing also in some depth the econometric approaches used. While some of these empirical studies can be linked to the theoretical mechanisms outlined above, in quite many cases the empirical results are bound to link resources to conflict without highlighting the particular channels at work.

The pioneering empirical contributions linking natural resource abundance to conflict (see e.g. Fearon and Laitin, 2003; and Collier and Hoeffler, 2004) have studied the overall impact of natural resources in general on conflict using pooled country-year level panels, finding indeed a positive association between resource wealth and conflict. From this starting point onwards, the literature has moved from more general to more specific, as far as both the types of natural resources studied, as well as the level of geographical aggregation is concerned.

\subsection{Types of natural resources}

In terms of resources studied, the one resource that has been found to be particularly dangerous for political stability is oil (Fearon and Laitin, 2003; Fearon, 2005; Humphreys, 2005; Ross, 2006, 2012). The most recent country-year level studies linking oil to civil conflict have put emphasis on the need to control for country fixed effects. Doing so, Cotet and Tsui (2013) do not find a robust impact of oil reserves on civil conflict, while Lei and Michaels (2014) find oil discoveries to boost the risk of civil wars. Using geographically disaggregate data, Dube and Vargas (2013) find positive oil price shocks to increase violence in Columbia, while Morelli and Rohner (2015) find that increases in oil inequality within a country lead to more fighting.

Another resource having been found to increase the risk of civil war are diamonds (Lujala et al., 2005; Humphreys, 2005; Ross, 2006, Olsson, 2007; and Lujala, 2010). Similarly, at a cell-level Berman et al. (2017) find that price increases for particular minerals increase armed conflict events in areas producing these minerals.

Finally, it has been found that the production of narcotics tends to rise the scope for conflict (Angrist and Kugler, 2008; Lujala, 2009; Mejia and Restrepo, 2015).

Interestingly, and in line with the feasibility of conflict channel discussed under section 2.2, lootable resources like alluvial gemstones, other minerals, narcotics and timber also tend to sustain, spread and prolong war effort during conflict (Fearon, 2004; Ross, 2006; Lujala, 2010; Berman et al., 2017). As such resources can more easily be appropriated by local rebel groups, they may indeed play a key role in rebel financing.

\subsection{Focusing on shocks and using disaggregate data}

In the quest of improving the identification strategy for studying the resources-conflict nexus there have been two broad trends in the literature, namely the focus on price or discovery shocks, as well as the 
use of more disaggregate data at the ethnic group or cell level, allowing to control for unobserved heterogeneity at the very local level, for example by the inclusion of cell fixed effects and country-year fixed effects.

As far as shocks are concerned, trade and commodity price shocks related to natural resources have indeed been found to increase the risk of conflict in some instances (Ross, 2006; Brückner and Ciccone, 2010; Besley and Persson, 2011; Dube and Vargas, 2013; Bazzi and Blattman, 2013; Berman et al., 2017).

Also the use of disaggregate data has become increasingly popular, with articles using such data including for example Angrist and Kugler (2008), Dube and Vargas (2013), Aragon and Rud (2013), Morelli and Rohner (2015), Esteban et al. (2015), Berman et al. (2017), and Sanchez de la Sierra (2017).

\section{Conclusion - How to Break the Conflict-Related Resource Curse?}

As pointed out above, there is on the whole convincing evidence that-at least in recent decadesnatural resource abundance is rather a detrimental than beneficial force for peace. A variety of channels link resource rents to the incentives of conflict, and various types of natural resources are susceptible to fuel war.

The above account is somewhat gloomy-to say the least. Are we doomed to be in a world where mother nature's riches create chaos and turmoil rather than wealth and prosperity? While curbing the conflict trap is not easy, there are some promising avenues for policies for peace.

First of all, it is important to keep in mind that the studies relating conflict to natural resource abundance draw on post-World War II data, and that their gloomy findings contrast considerably with historical case studies where resource abundance could be an engine of growth without spreading civil conflict, such as for example the case of coal in the United States or in Europe during Industrialisation (see the discussion under section 2.8). What these historical success stories, as well as current ones such as Norway or Botswana, have in common is that they have occurred in countries with strong state capacity and reliable institutions. As shown by Mehlum et al. (2006), the negative effects of natural resources only predominate if institutions are of a poor quality. Norway's oil, for example, indeed has a rather beneficial impact, by fueling the Sovereign Wealth Fund, contrasting sharply with the detrimental effects in numerous other countries.

Second, transparency and good corporate governance matter. Berman et al. (2017) find that the negative effects of mining price surges can be partially attenuated if transparency initiatives limit illegal trading and in situations where the mining firms involved have good social responsibility records.

Third, channeling the natural resource manna from heaven into education is promising. De la Brière et al. (2017) and Rohner (2017) show that indeed in many situations investing resource wealth in human capital can foster future growth and reduce distributional conflicts.

While these three avenues may be auspicious, the relative scarcity of recent contributions proposing solutions to break the conflict-related resource curse suggests that there is still much further scope for 
studying which policies may turn natural resources into an engine for growth without increasing the risk of conflict. A challenging, yet important step consists in understanding in more depth the contrast between the recent literature on conflict finding in general harmful effects of natural resources and the literature in economic history finding that resource abundance has in several cases played a positive role. Future research focusing on the contexts, institutional arrangements, and policy environments in which resource abundance can be a blessing is very much encouraged.

\section{References:}

Angrist, Joshua and Adriana Kugler, 2008, "Rural Windfall or a New Resource Curse? Coca, Income, and Civil Conflict in Colombia", Review of Economics and Statistics 90: 191-215.

Aragon, Fernando, and Juan Pablo Rud, 2013, "Natural Resources and Local Communities: Evidence from a Peruvian Gold Mine", American Economic Journal: Economic Policy 5: 1-25.

Baland, Jean-Marie and Patrick Francois, 2000, "Rent-Seeking and Resource Booms", Journal of Development Economics 61: 527-42.

Barenbaum, Joshua, Vladislav Ruchkin, and Mary Schwab-Stone, 2004, "The psychological aspects of children exposed to war: practice and policy initiatives", Journal of Child Psychology and Psychiatry 45: 41-62.

Bauer, Michal, Christopher Blattman, Julie Chytilová, Joseph Henrich, Edward Miguel, and Tamar Mitts, 2016, „Can War Foster Cooperation?”, Journal of Economic Perspectives 30: 249-274.

Bazzi, Samuel, and Chris Blattman, 2014, "Economic Shocks and Conflict: The Evidence from Commodity Prices", American Economic Journal: Macroeconomics 6: 1-38.

Bell, Curtis, and Scott Wolford, 2015, "Oil Discoveries, Shifting Power, and Civil Conflict", International Studies Quarterly 59: 517-530.

Berman, Nicolas, Mathieu Couttenier, Dominic Rohner and Mathias Thoenig, 2017, "This mine is mine! How minerals fuel conflicts in Africa", American Economic Review 107: 1564-1610.

Brückner, Markus, and Antonio Ciccone, 2010, "International Commodity Prices, Growth and the Outbreak of Civil War in Sub-Saharan Africa", Economic Journal 120: 519-534.

Brière, Bénédicte de la, Deon Filmer, Dena Ringold, Dominic Rohner, Karelle Samuda, and Anastasiya Denisova, 2017, From Mines and Wells to Well-Built Minds, Washington DC: World Bank.

Besley, Timothy, and Torsten Persson, 2011, Pillars of Prosperity, Princeton NJ: Princeton University Press.

Caselli, Francesco and Wilbur John Coleman II, 2013, "On the Theory of Ethnic Conflict," Journal of the European Economic Association 11: 161-192. 
Caselli, Francesco, and Guy Michaels, 2013, "Do Oil Windfalls Improve Living Standards? Evidence from Brazil." American Economic Journal: Applied Economics, 5: 208-38.

Caselli, Francesco, Massimo Morelli, and Dominic Rohner, 2015, "The Geography of Inter-State Resource Wars", Quarterly Journal of Economics 130: 267-315.

Clay, Karen, 2011, "Natural Resources and Economic Outcomes", in Paul Rhode, Joshua Rosenbloom and David Weiman (eds.), Economic Evolution and Revolution in Historical Time, Redwood City CA: Stanford University Press.

Collier, Paul, 2007, The Bottom Billion: Why the Poorest Countries Are Failing and What Can Be Done About It, Oxford, Oxford University Press.

Collier, Paul and Anke Hoeffler, 2004, "Greed and Grievance in Civil War", Oxford Economic Papers 56: 563-95.

Collier, Paul, Anke Hoeffler, and Dominic Rohner, 2009, "Beyond Greed and Grievance: Feasibility and Civil War", Oxford Economic Papers 61: 1-27.

Cotet, Anca M., and Kevin K. Tsui, 2013, "Oil and Conflict: What Does the Cross Country Evidence Really Show?" American Economic Journal: Macroeconomics 5: 49-80.

Couttenier, Mathieu, Pauline Grosjean, and Marc Sangnier, 2017, "'The Wild West is Wild: The Homicide Resource Curse", Journal of the European Economic Association 15: 558-585.

Couttenier, Mathieu, Veronica Preotu, Dominic Rohner and Mathias Thoenig, 2016, "The Violent Legacy of Victimization: Post-Conflict Evidence on Asylum Seekers, Crimes and Public Policy in Switzerland", CEPR Discussion Paper 11079.

Dal Bó, Ernesto and Pedro Dal Bó, 2011, "Workers, Warriors, and Criminals: Social Conflict in General Equilibrium", Journal of the European Economic Association 9: 646-677.

DeRouen, Karl, and Jacob Bercovitch, 2008, "Enduring Internal Rivalries: A New Framework for the Study of Civil War", Journal of Peace Research 45: 55-74.

Dube, Oendrila, and Juan Vargas, 2013, "Commodity Price Shocks and Civil Conflict: Evidence from Colombia", Review of Economics Studies 80: 1384-1421.

Esteban, Joan, Massimo Morelli, and Dominic Rohner, 2015, "Strategic Mass Killings", Journal of Political Economy 123: 1087-1132.

Fearon, James, 2004, "Why Do Some Civil Wars Last So Much Longer than Others?" Journal of Peace Research 41: 275-301.

Fearon, James, 2005, "Primary Commodity Exports and Civil War," Journal of Conflict Resolution 49: 483507. 
Fearon, James and David Laitin, 2003, "Ethnicity, Insurgency, and Civil War", American Political Science Review 97: 75-90.

Ghobarah, Hazen, Paul Huth and Bruce Russett, 2003, "Civil Wars Kill and Maim People-Long After the Shooting Stops", American Political Science Review 97: 189-202.

Grossman, Herschel and Juan Mendoza, 2003, "Scarcity and appropriative competition," European Journal of Political Economy 19: 747-58.

Hillbom, Ellen, 2015, "Botswana: Caught in a natural resource trap" in Marc Badia-Miró, Vincente Pinilla, Henry Willebald (eds.), Natural Resources and Economic Growth: Learning from History, Abingdon: Routledge.

Hodler, Roland, 2006, "The curse of natural resources in fractionalized countries," European Economic Review 50: 1367-86.

Humphreys, Macartan, 2005, "Natural Resources, Conflict, and Conflict Resolution: Uncovering the Mechanisms," Journal of Conflict Resolution 49: 508-37.

Le Billon, Philippe, 2001, "The political ecology of war: natural resources and armed conflicts," Political Geography 20: 561-584.

Lei, Yu-Hsiang, and Guy Michaels, 2014, “Do Giant Oil Field Discoveries Fuel Internal Armed Conflicts?", Journal of Development Economics 110: 139-157.

Lujala, Paivi, 2009, "Deadly Combat over Natural Resources: Gems, Petroleum, Drugs, and the Severity of Armed Civil Conflict", Journal of Conflict Resolution 53: 50-71.

Lujala, Paivi, 2010, "The Spoils of Nature: Armed Civil Conflict and Rebel Access to Natural Resources," Journal of Peace Research 47: 15-28.

Lujala, Paivi, Nils Petter Gleditsch and Elisabeth Gilmore, 2005, "A Diamond Curse? Civil War and a Lootable Resource," Journal of Conflict Resolution 49: 538-62.

Matsen, Egil, Gisle Natvik, and Ragnar Torvik, 2017, "Petro Populism", Journal of Development Economics, forthcoming.

Mehlum, Halvor, Karl Moene and Ragnar Torvik, 2006, "Institutions and the Resource Curse", Economic Journal 116: 1-20.

Mejia, Daniel and Pascual Restrepo, 2015, "Bushes and Bullets: Illegal Cocaine Markets and Violence in Colombia", Boston University, working paper.

Morelli, Massimo, and Dominic Rohner, 2015, "Resource Concentration and Civil Wars", Journal of Development Economics 117: 32-47.

Olsson, Ola, 2007, "Conflict diamonds", Journal of Development Economics 82: 267-286. 
Ploeg, Frederick van der, 2011, "Natural resources: curse or blessing?", Journal of Economic Literature 49: 366-420.

Ploeg, Frederick van der, 2017, "Political economy of dynamic resource wars", Journal of Environmental Economics and Management, forthcoming.

Ploeg, Frederick van der and Dominic Rohner, 2012, "War and Natural Resource Exploitation," European Economic Review 56: 1714-1729.

Reuveny, Rafael and John Maxwell, 2001, "Conflict and Renewable Resources," Journal of Conflict Resolution 45: 719-42.

Rohner, Dominic, 2017, "Barrels, Books and Bullets: How Education Can Prevent Conflict and Promote Development in Resource Rich Countries", mimeo, University of Lausanne.

Rohner, Dominic, Mathias Thoenig, and Fabrizio Zilibotti, 2013, "Seeds of Distrust: Conflict in Uganda", Journal of Economic Growth 18: 217-252.

Rohner, Dominic, Mathias Thoenig, and Fabrizio Zilibotti, 2013b, "War Signals: A Theory of Trade, Trust and Conflict", Review of Economic Studies 80: 1114-1147.

Ross, Michael, 2004, "What Do We Know About Natural Resources and Civil War?", Journal of Peace Research 41: 337-56.

Ross, Michael, 2006, "A closer look at oil, diamonds, and civil war", Annual Review of Political Science 9: 265-300.

Ross, Michael, 2012, The Oil Curse: How Petroleum Wealth Shapes the Development of Nations, Princeton NJ: Princeton University Press.

Sanchez de la Sierra, Raul, 2017, "On the Origin of States: Stationary Bandits and Taxation in Eastern Congo", working paper, UC Berkeley.

Shemyakina, Olga, 2011, "The effect of armed conflict on accumulation of schooling: Results from Tajikistan", Journal of Development Economics 95: 186-200.

Wright, Gavin, and Jesse Czelusta, 2006, "Resource-Based Growth: Past and Present" in Daniel Lederman and William Maloney (eds.), Natural Resources: Neither Curse nor Destiny, Washington DC: World Bank. 